$\xi=$ 不

\title{
Correlation of physical and mechanical properties with ultrasonic pulse velocities of sandstones in Çenedă̆ Kocaeli-Turkey
}

\author{
M. Aşcı ${ }^{1}$ *, I. Kaplanvural ${ }^{1}$, A. Karakaş $^{2}$, Ö. K. Şahin ${ }^{3}$, C. Kurtuluş ${ }^{1}$ \\ ${ }^{1}$ Kocaeli University, Department of Geophysical Engineering, Umuttepe Campus, Turkey \\ ${ }^{2}$ Kocaeli University, Department of Geological Engineering, Umuttepe Campus, Turkey \\ ${ }^{3}$ Missouri University of Science and Technology, G\&G Department, Rolla, MO, 65401, USA \\ *Corresponding author E-mail: masci@kocaeli.edu.tr
}

\begin{abstract}
Correlation of physical and mechanical properties with ultrasonic pulse velocities (UPV) of sandstones in Çenedağ, Kocaeli-Turkey, NW was performed in this study. Physical and mechanical properties were defined and the relationships among the uniaxial compressive strength (UCS), porosity, void ratio, point load strength index Is(50),Schmidt hardness (RN) and bulk mass density by weight with ultrasonic pulse velocity of pink and cream colored sandstone unit of Lower Ordovician Çenedağ formation were investigated. In the scope of this research, 16 sandstone specimens were collected from various locations of Çenedağ formation in Çenedağ-Kocaeli, Turkey and laboratory experiments were implemented. Later, the statistical correlations were performed by regression analysis to evaluate the relationships between these properties and ultrasonic pulse velocity. Reasonably good correlations were determined between the UPV and physical and mechanical properties.
\end{abstract}

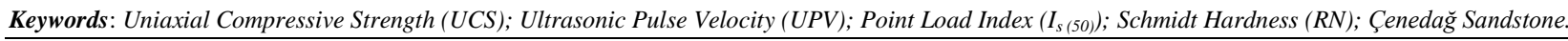

\section{Introduction}

Physical and mechanical properties of rocks are important parameters used in designing engineering projects. Determination of these properties in laboratory is a necessary step to be accomplished. These properties have been long determined in laboratory by routine tests described in the miscellaneous standards. Mechanical properties such as uniaxial compressive strength (UCS) and point load index $\left(\mathrm{Is}_{\mathrm{S}(50))}\right)$ of the rocks are widely used in civil and rock engineering applications. There are number of studies on deriving empirical equations between UCS and Is (50) (D'Andrea et al. 1964; Broch and Franklin 1972; Bieniawski, 1975; Hassani et al. 1980; Read et al. 1980, Forster 1983; Gunsallus and Kulhway, 1984; Cargil and Shakoor1990; Grasso et al. 1992; Chou and Wong 1996, Kahraman 1996; Başarır et al. 2004; Kurtuluş and Çakır 2009).

Physical properties such as density, porosity, void ratio, water content and water absorption are commonly determined in material or rock laboratories. Determination of these properties in laboratory is tedious, expensive and time-consuming. Instead, ultrasonic pulse velocity (UPV) testing is lately used to estimate physical and mechanical properties of rocks. Many researchers studied physical and mechanical properties of different rock types with destructive and non-destructive test methods and made reasonable correlations between the properties. Yaşar and Erdoğan (2004) correlated UPV with density and UCS with Young's modulus of carbonate rocks. Kahraman and Yeken (2008) determined the physical properties of carbonate rocks from UPV and obtained good correlations. Inoue and Ohomi (1981), Göktan (1988),
Kahraman (2001) studied the relationships between UCS and UPV.

This study determined the physical properties such as bulk mass density, porosity, water absorption by mass, Schmidt Hammer rebound values and mechanical properties such as UCS and Is(50) of sixteen sandstone core specimens in laboratory. The UPV measurements were also conducted on the same test specimens and correlations of physical and mechanical properties with UPV were carried out.

\section{Geology of investigation area}

Investigation area is located in Kocaeli Peninsula, NW Turkey (Fig. 1). The oldest formation in the study area is the Sopal formation with arkosic sand stone deposited in Lower Ordovician. The Upper Ordovician Çenedağ formation consisted of quartzite overlies the Sopalı formation conformably. The Lower Devonian Çınarlıdere formation consisting of gray wacke and shale rocks overlay the Sopalı and Çenedağ formations angular unconformably. Fig. 2 shows the geology of the study area

The rock specimens are taken from the Çenedağ formation named by Çakır (2000). Kaya (1978) called the same formation as "Aydos formation" at the western part of Kocaeli Peninsula. Çenedağ formation is composed of white, dirty white, pinky white, light gray orthoquartzite sandstone. The strata are generally massive and crossbedding is rarely observed at Çenedağ Hill. The orthoquartzites contain semi-rounded quartz grains appearing under microscope. Quartz content is higher than $95 \%$ with very little fine-grained matrix. Sandstone matrix has a $10 \%$ sericite and the other portion is composed of quartz and rock fragments. There are 
no fossils in the orthoquartzites. Igneous quartz type is common, but metamorphic quartz type is seldom in thin sections. According to Altınlı (1968), igneous, volcanic and metamorphic quartz types are seen in thin sections. Therefore, granite, granodiorite, gneiss and mica schist could be the source of these sediments and rocks in the region. The Çenedağ formation outcrops at Karadere-Zirze area (approximately $250 \mathrm{~km}$ east of the study area). Thickness of the formation is about $87 \mathrm{~m}$ at Çenedağ hill according to Çakır (2000).

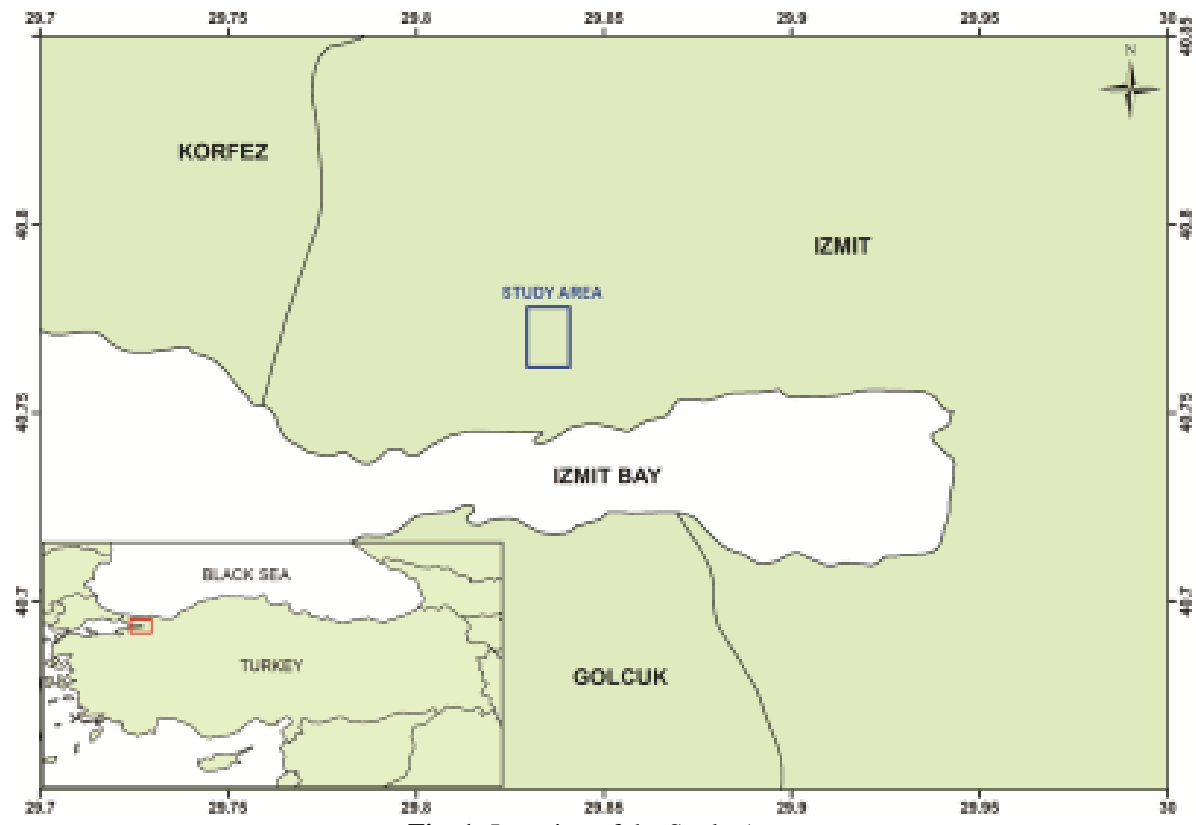

Fig. 1: Location of the Study Area.
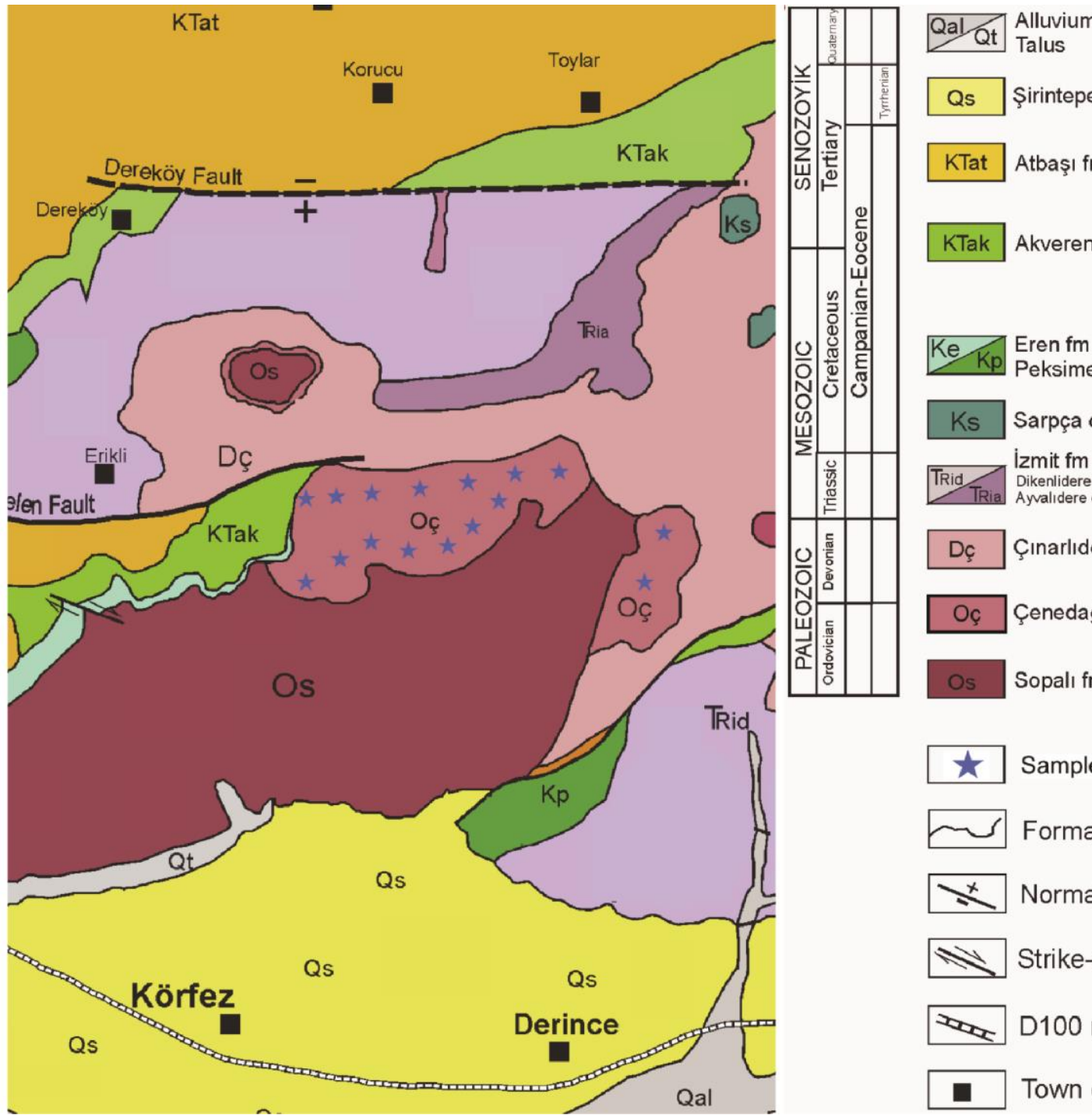

Qs Şirintepe fm

KTat Atbaşı fm

KTak Akveren fm

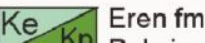

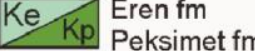

Ks Sarpça cong

İzmit fm

TRid Tikenlidere sandstone

Ayvalidere cong.

Dç Çınarlıdere fm

Oç Çenedağ fm

Os Sopalı fm

$\star$ Sample Locations

$\sim$ Formation boundary

$\underset{x}{x}$ Normal fault

Strike-slip fault

Dow D100 road

- Town center

Fig. 2: Geology Map of the Study Area (Modified From Çakır, 2000). 


\section{Experimental procedure}

The sandstone specimens for the present study were collected from the different places of Çenedağ located in Kocaeli, NW of Turkey. Relatively, homogeneous levels in sandstone outcrops were collected randomly in 16 different locations of the study area in order to apply the mechanical (UCS, Is(50)), UPV and physical ( $\mathrm{S}_{\mathrm{a}}, \mathrm{n}_{\text {eff, }} \square$, Schmidt hardness) tests. The specimens were prepared from randomly collected irregular blocks (approximately $30 \times 40 \times 50 \mathrm{~cm}$ ) taken from the sandstone outcrops in the field. Fig. 2 displays the locations of rock samples taken. The sandstone specimens were prepared as cylindrical shapes with 100-110 mm length and $54 \mathrm{~mm}$ diameter in laboratory according to ASTM (2001) and ASTM (2010). One core specimen was prepared for UCS and one core specimen was prepared for other tests from each rock blocks according to the dimension standards. Physical and mechanical properties were determined and UPV tests were run for the specimens specifically prepared for the tests in the laboratory.

\section{Determination of physical properties}

The physical properties determined in the study are water absorption, effective porosity, bulk mass density and Schmidt hardness ISRM (2007) method was adopted to attain the water absorption and effective porosity properties. Saturation technique is applied in order to determine the effective porosity of sandstone specimens. The weight of all specimens was measured before the water immersion. All samples of sandstone were immersed in water and waited for a period of 48 hours. Later, the weight of saturated specimens was measured with $0.01 \mathrm{~g}$ accuracy. The effective porosities were found from weight differences between saturated and unsaturated weights of all specimens. The bulk mass density of each cylindrical specimen was determined by using oven method For this process, the specimens were placed in an electrical oven at $105^{\circ} \mathrm{C}$ for 24 hours and were dried at room temperature. The density of the test specimens was obtained dividing the mass of each specimen by its bulk volume multiplied by 100 . The saturation method was utilized for defining the effective porosity of rock specimens. In order to determine Schmidt hardness of rock specimens, an N-type Schmidt Hammer with impact energy of 2,207 $\mathrm{Nm}$ was used. Twenty Schmidt Hammer blows were applied to each specimen. The average value of ten high hits was considered as Schmidt Hammer Rebound value of each specimen (ISRM, 2007).

\section{Determination of mechanical properties}

The mechanical properties determined in the study include the uniaxial compressive strength (UCS) and point load strength. The characterization of rock materials by the UCS is one of the most important properties. In this case, the compressive strength of rock specimens is obtained from the results of UCS (ASTM 2001; ASTM 2010). Strength classification of rocks can be determined by Is $(50)$ as an index test which can be used for estimation of other rock parameters such as elasticity modules, tensile strength, Schmidt hardness, $\mathrm{P}$ wave velocity (Kurtulus 2011).

The UCS of the specimens was acquired by applying each specimen an incremental loading at a nearly constant rate by a $150 \mathrm{kN}$ capacity UTEST hydraulic testing machine according to ASTM D7012-10 (2010). The point load index (Is $\left.{ }_{(50)}\right)$ of each core specimen was defined by placing each specimen between two pointed conical steels of a $50 \mathrm{kN}$ capacity point load machine according to ASTM D5731-08 (2008).

\section{Ultrasonic pulse velocity (UPV) measure- ments}

The Ultrasonic pulse velocity (UPV) measurements were carried out using DT Quist-120t tester with the transducers having $54 \mathrm{kHz}$ frequency. The UPV measurements were performed for all sandstone specimens in accordance with ISRM (1981) and ASTM (1978). The transmitter was placed on one side and the receiver was placed on the other side of the specimen. UPV was measured on each sandstone rock specimen. In order to achieve a good coupling both sides of each core specimens were polished and coated with stiffer grease. Several measurements were taken for each core specimen to obtain an accurate average UPV value. The UPV was computed dividing the length of specimen by pulse travel time. The UPV measurements were averaged to reach an arithmetic mean value used in the statistical analyses. The UPV is calculated by the formula (1).

$\mathrm{V}_{\mathrm{UPV}}=\frac{\mathrm{L}}{\mathrm{t}}$

Here, $\mathrm{L}$ is the length of the specimen in meter; $\mathrm{t}$ is the travel time of the ultrasonic pulse wave in second.

\section{Statistical analyses}

Statistical analyses made possible constructing correlation relationships and regression equations. The correlation coefficient of determination $\left(\mathrm{R}^{2}\right)$ was computed to define the strength of relationship. Table 1 presents the summary data of bulk mass density $(\rho)$,effective porosity ( $n_{\text {eff }}$ ), water absorption by mass $\left(S_{a}\right)$, void ratio (e), uniaxial compressive strength (UCS), point load index (Is(50)) and ultrasonic pulse velocity (UPV). The results of UCS were correlated with I s (50) and UPV (Fig. 3a and b).A simple least square linear regression method was applied to data in order to compare the measurements for the statistical analysis. Formula 2 was used to obtain the regression equations between UPV values and, the physical and mechanical properties and UPV.

$\mathrm{Y}=\mathrm{B}_{0}+\mathrm{B}_{1} \mathrm{X}$

Here, $\mathrm{X}$ is the independent variable, $\mathrm{Y}$ is the depended coefficient, $\mathrm{B}_{0}$ is the value of $\mathrm{Y}$ when $\mathrm{X}=0, \mathrm{~B}_{1}$ is the regression coefficient. Statistical analyses were carried out by using the Matlab R2009B version of software. Also, graphics of the linear regressions were plotted by using the same software. 
Table 1: Laboratory Results Of Physical, Mechanical Properties and Ultrasonic Pulse Velocity (UPV) Measurements of Specimens

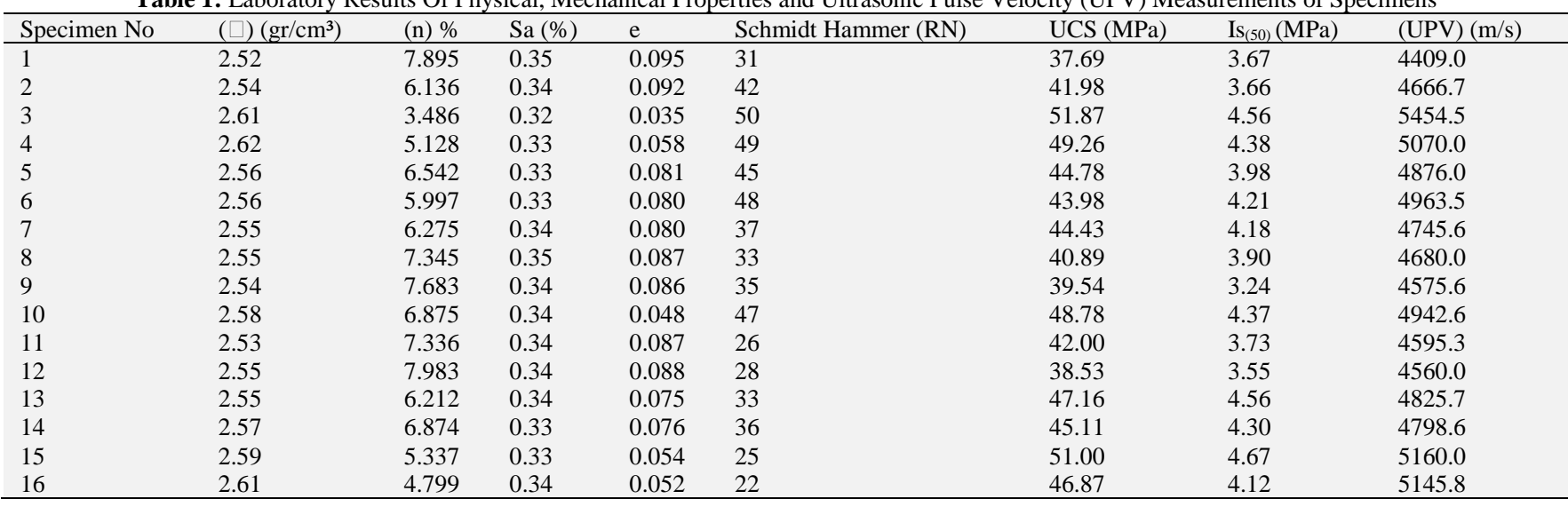

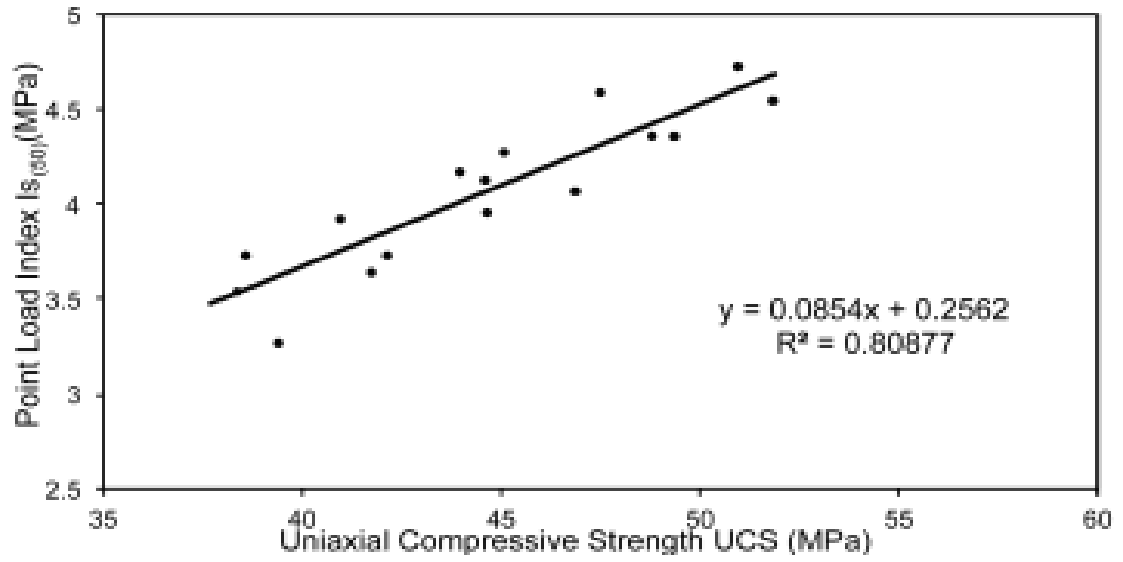

Fig. 3: (A) Scatter Plot of Point Load Strength Index and Uniaxial Compressive Strength.

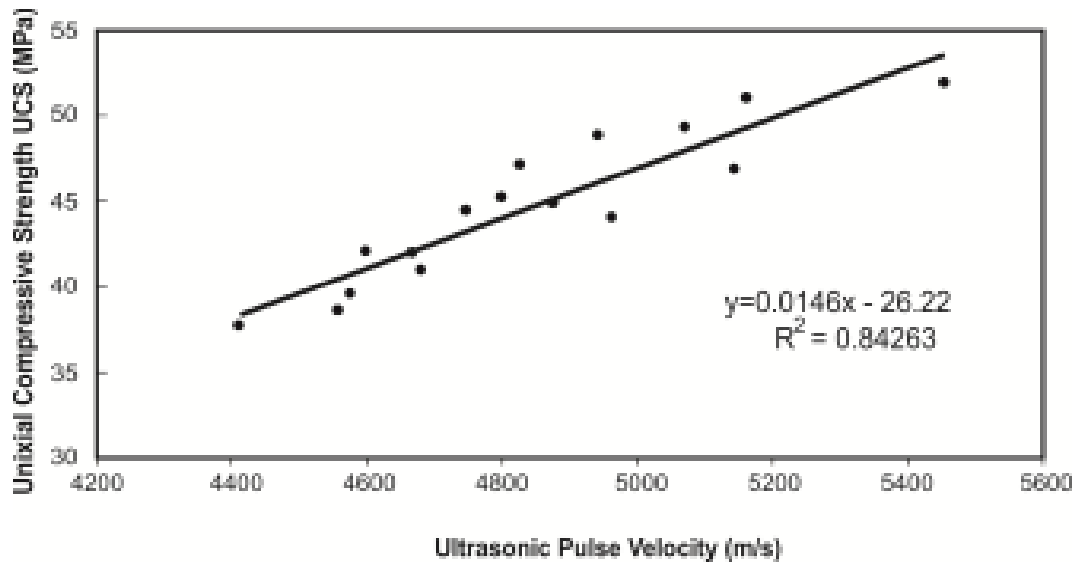

Fig. 3: (B) Scatter Plot of Uniaxial Compressive Strength and Ultrasonic Pulse Velocity.

The porosity, void ratio, bulk density, water absorption by mass and Schmidt Hardness properties were also correlated with UPV as well (Fig. 4a and b), (Fig. 5a and b) and (Fig. 6). Regression analysis was performed and equations of the best fit line were determined.

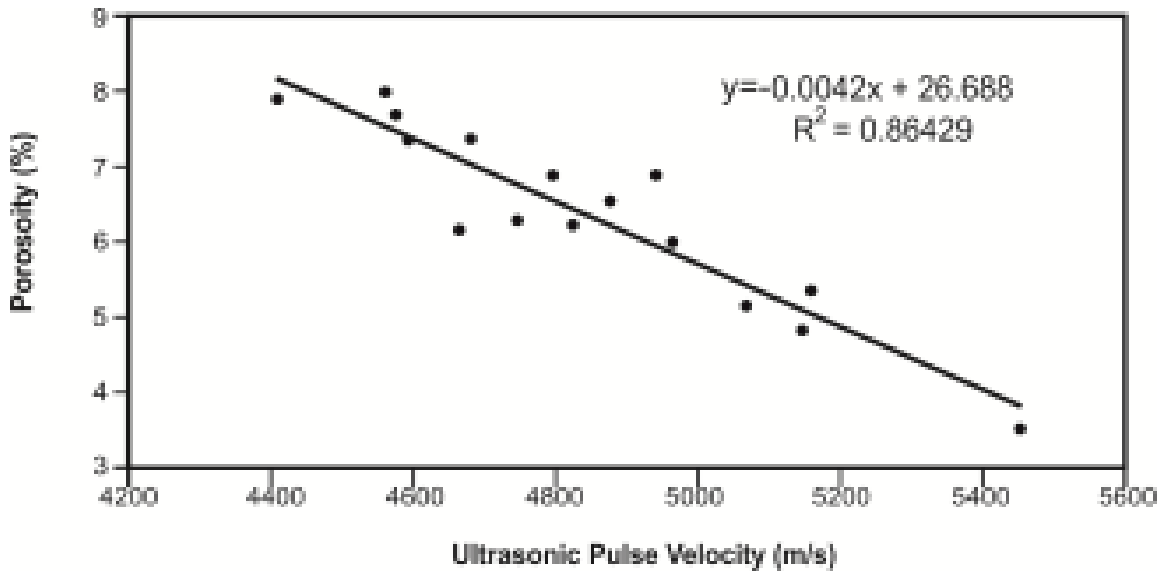

Fig. 4: (A) Scatter Plot of Porosity and Ultrasonic Pulse Velocity. 


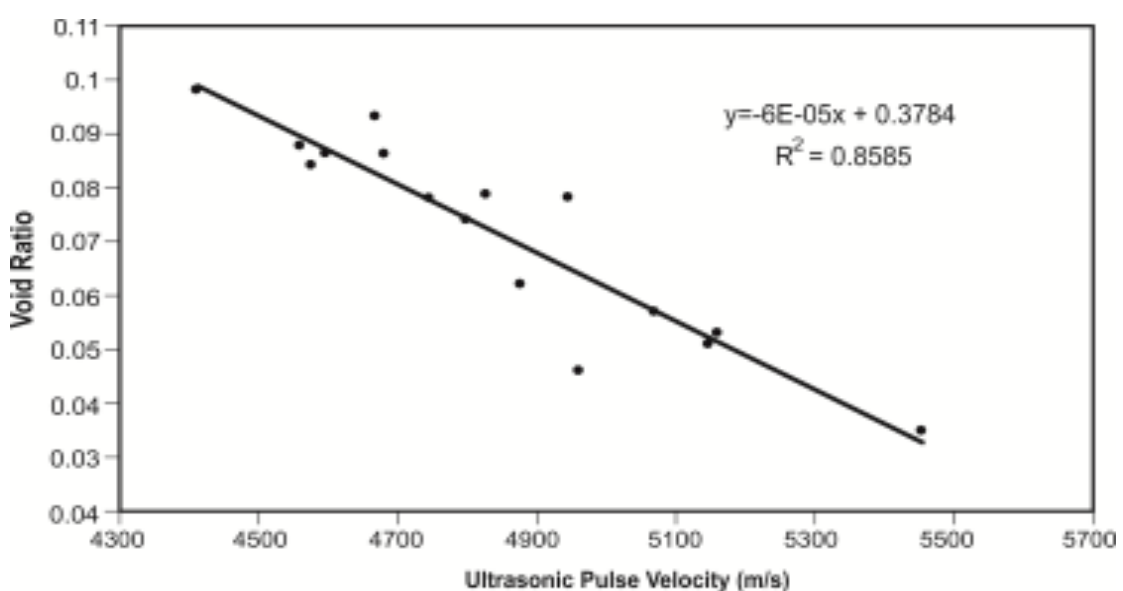

Fig. 4: (B) Scatter Plot of Void Ratio and Ultrasonic Pulse Velocity.

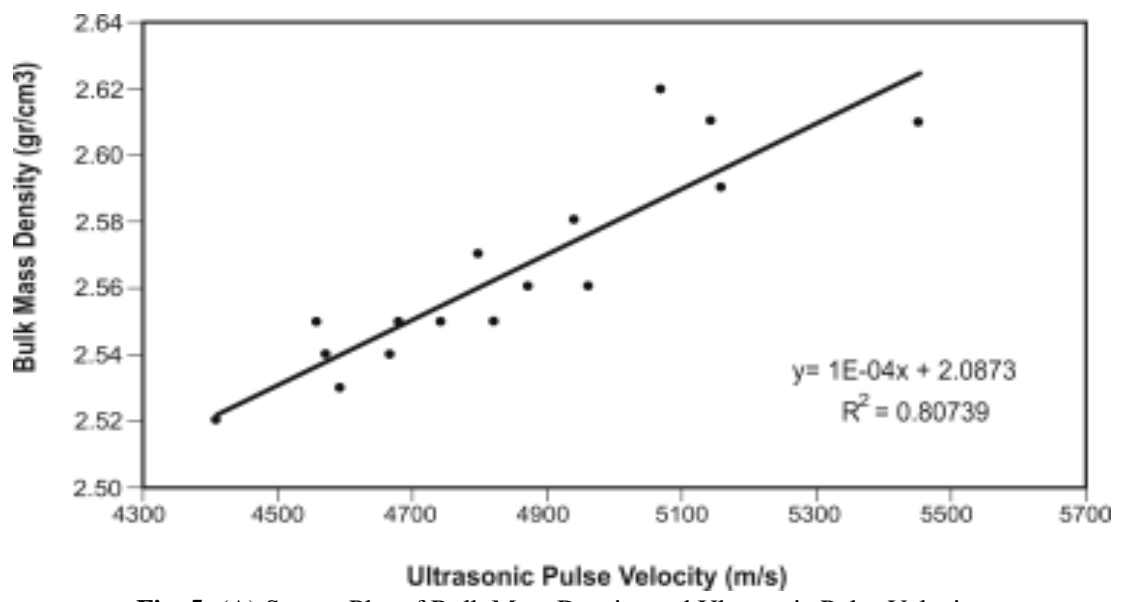

Fig. 5: (A) Scatter Plot of Bulk Mass Density and Ultrasonic Pulse Velocity.

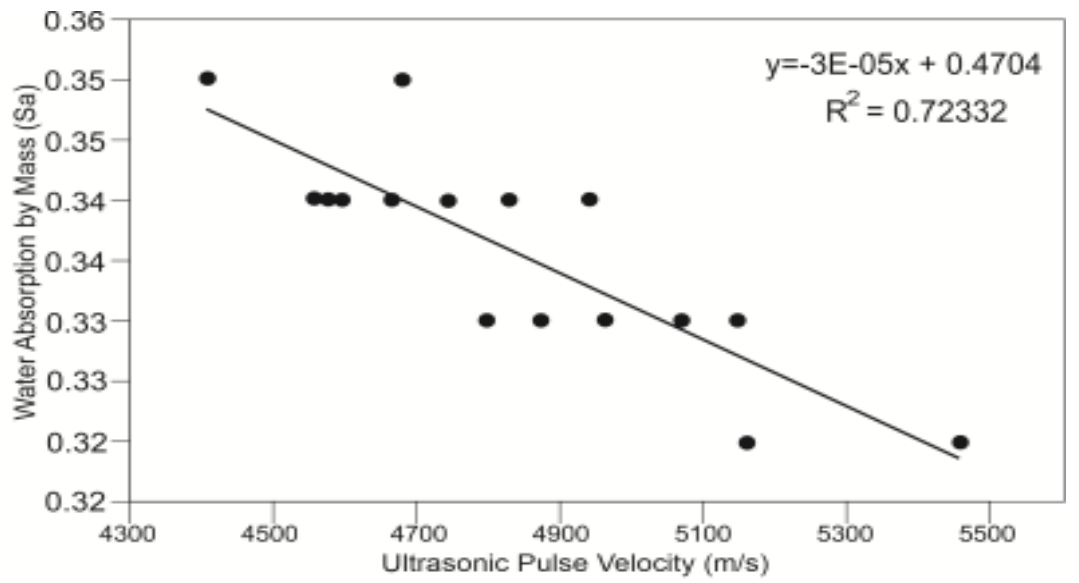

Fig. 5: (B) Scatter Plot of Water Absorption by Mass and Ultrasonic Pulse Velocity.

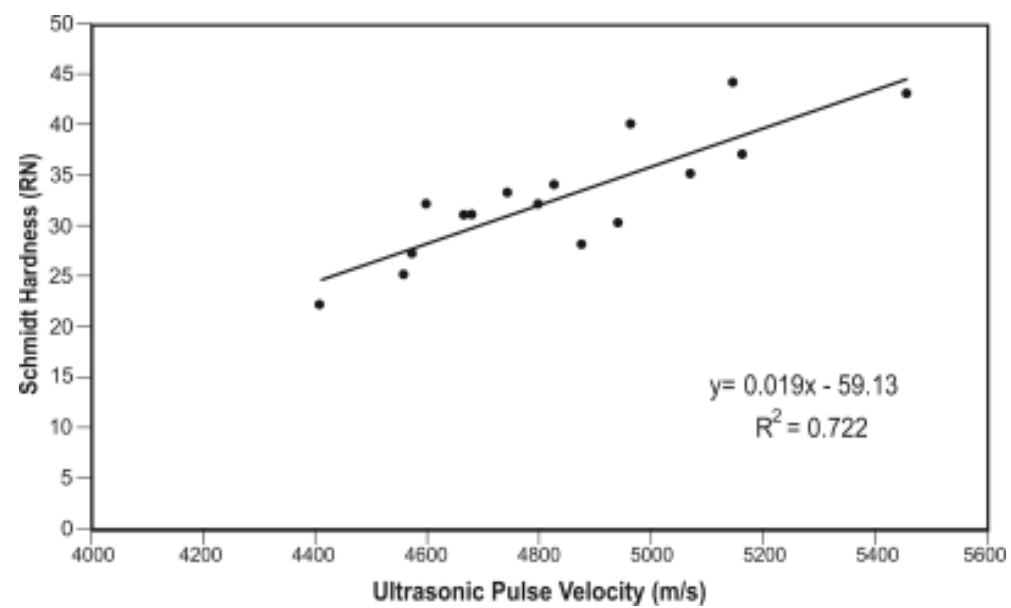

Fig. 6: Scatter Plot of Schmidt Hardness and Ultrasonic Pulse Velocity. 
The empirical relationships between UCS and $\mathrm{I}_{\mathrm{S}(50)}$ are given in Table 2. The relationships developed among the physical, mechanical and UPV are given in Table 3. The relationships between UCS and UPV and other authors obtained in this study are given in Table 4.

Table 2: Relations between UCS and Is ${ }_{(50)}$ given by different authors and this study

\begin{tabular}{ll}
\hline Author & Model \\
\hline D'andre et al., (1964) & $\mathrm{UCS}=15.3 \mathrm{I}_{\mathrm{s}(50)}+16.3$ \\
Broch \& Franklin (1972) & $\mathrm{UCS}=24 \mathrm{I}_{\mathrm{s}(50)}$ \\
Bieniawski (1975) & $\mathrm{UCS}=23 \mathrm{I}_{\mathrm{s}(50)}$ \\
Hassani et. Al., (1980) & $\mathrm{UCS}=29 \mathrm{I}_{\mathrm{s}(50)}$ \\
Read et al., (1980) & \\
For sedimentary formation & $\mathrm{UCS}=16 \mathrm{I}_{\mathrm{s}(50)}$ \\
For bazalt & $\mathrm{UCS}=20 \mathrm{I}_{\mathrm{s}(50)}$ \\
Forster (1983) & $\mathrm{UCS}=14.5 \mathrm{I}_{\mathrm{s}(50)}$ \\
Gunsallus and Kulhway (1984) & $\mathrm{UCS}=16.5 \mathrm{I}_{\mathrm{s}(50)}+51$ \\
ISRM (1981) & $\mathrm{UCS}=25 \mathrm{I}_{\mathrm{s}(50)}$ \\
Cargill and Shakoor (1990) & $\mathrm{UCS}=23 \mathrm{I}_{\mathrm{s}(50)}+13$ \\
Grasso et al., (1992) & $\mathrm{UCS}=9.30 \mathrm{I}_{\mathrm{s}(50)}+20.04$ \\
Chau and Wong (1996) & $\mathrm{UCS}=12.5 \mathrm{I}_{\mathrm{s}(50)}$ \\
Kahraman (1996) & \\
For semi coal formation & $\mathrm{UCS}=23.62 \mathrm{I}_{\mathrm{s}(50)}-2.69$ \\
For other formation & $\mathrm{UCS}=8.48 \mathrm{I}_{\mathrm{s}(50)}+9.51$ \\
Başarir and Kumral (2004) & $\mathrm{UCS}=10.957 \mathrm{I}_{\mathrm{s}(50)}$ \\
This study & $\mathrm{UCS}=9.4678 \mathrm{I}_{\mathrm{s}(50)}+6.1065$ \\
\hline
\end{tabular}

Table 3: Relationships developed among the physical, mechanical and ultrasonic pulse velocity (UPV) values

\begin{tabular}{ll}
\hline $\mathrm{UCS}=9.4678 \mathrm{Is}_{(50)}+6.1065$ & $\mathrm{R}^{2}=0.8088$ \\
\hline $\mathrm{UCS}=0.0146(\mathrm{UPV})-26.227$ & $\mathrm{R}^{2}=0.8426$ \\
$\mathrm{n}=-0.0042(\mathrm{UPV})+26.688$ & $\mathrm{R}^{2}=0.8643$ \\
$\mathrm{e}=-6 \mathrm{E}-05(\mathrm{UPV})+0.3784$ & $\mathrm{R}^{2}=0.8585$ \\
$\square=1 \mathrm{E}-04(\mathrm{UPV})+2.0873$ & $\mathrm{R}^{2}=0.8074$ \\
$\mathrm{Sa}=-3 \mathrm{E}-0.5(\mathrm{UPV})+0.4704$ & $\mathrm{R}^{2}=0.8088$ \\
$\mathrm{RN}=0.0266(\mathrm{UPV})-88.903$ & $\mathrm{R}^{2}=0.7216$ \\
\hline
\end{tabular}

Table 4: The relations between UCS and UPV given by different authors and this study

\begin{tabular}{ll}
\hline Author & Model \\
\hline Inoue and Ohomi (1981) & $\mathrm{UCS}=\mathrm{k} \gamma \mathrm{V}_{\mathrm{p}}{ }^{2}+\mathrm{A}$ \\
Goktan (1988) & $\mathrm{UCS}=0.036 \mathrm{Vp}-31.18$ \\
Kahraman (2001) & $\mathrm{UCS}=9.95 \mathrm{~V}_{\mathrm{p}}{ }^{1.21}$ \\
Başarır and Kumral (2004) & $\mathrm{UCS}=0.68 \rho \mathrm{V}_{\mathrm{p}}^{2.69}$ \\
This study (UPV=Vp) & $\mathrm{UCS}=0.0146 \mathrm{Vp}-26.227$ \\
\hline
\end{tabular}

\section{Discussion and conclusion}

Physical and mechanical properties and UPVs of sandstone were used to derive the relations among them. For this aim, the relations between the UCS and $\mathrm{I}_{\mathrm{s}(50)}$, UCS and UPV, and porosity, void ratio, bulk mass density, water absorption by mass, Schmidt's hardness and UPV properties were analyzed in this study. Leastsquares regression analysis showed that there is a very good linear correlation between UCS and $\mathrm{I}_{\mathrm{s}(50)}\left(\mathrm{R}^{2}=0.8088\right)$. UCS increases

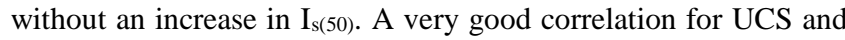
UPV was obtained with linear function with a correlation coefficient of $\mathrm{R}^{2}=0.8426$. UCS increases without an increase in UPV. The results of correlations between porosity and UPV $\left(\mathrm{R}^{2}=0.8643\right)$, void ratio and UPV $\left(\mathrm{R}^{2}=0.8585\right)$, density and UPV $\left(\mathrm{R}^{2}=0.8074\right)$, and water absorption by mass and UPV $\left(\mathrm{R}^{2}=0.7233\right)$, Schmidt's hardness and UPV $\left(\mathrm{R}^{2}=0.7216\right)$, are reasonably good. The results also indicated that a decrease in porosity and void ratio resulted in an increase in UPV and an increasing of bulk density and water absorption by mass of sandstone yielded an increase in UPV. The equations derived from the correlations of UCS and I s (50), and UCS and UPV in this study were shown in Tables 3 and 4 along with other correlations derived by different authors.

In this study, the equation determined for UCS and $\mathrm{I}_{\mathrm{s}(50) \text { is similar }}$ to equations given by Grasso et al.(1992), Kahraman (1996), D'Andre et al.(1964) and the equation developed for UCS and UPV is rather similar to equation given by Göktan (1988). The empirical equations obtained in this study can be used for the prediction of physical and mechanical properties of sandstones of Çenedağ formation. In order to increase the sensitivity of the equations determined during this study, further studies are necessary.

\section{References}

[1] Altınlı, İ.E. (1968). İzmit-Hereke Kurucadağ Alanının Jeoloji İncelemesi. MTA Dergisi, 71, 1-26 (in Turkish).

[2] ASTM (1978). Standard method for laboratory determination of pulse velocities and ultrasonic elastic constants of rocks. Annual Book of ASTM Standards, Part 19, D. 2845-69:356-36.

[3] ASTM (2001). Standard practice for preparing rock core specimens and determining dimensional and shape tolerances. American Society for Testing and Materials. D4543.

[4] ASTM (2008). Standard Practices for Preparing Rock Core as Cylindrical Test Specimens and verifying Conformance to Dimensional and Shape Tolerances. D4543-08.

[5] ASTM (2010). Standard Test Method for Compressive Strength and Elastic Moduli of Intact Rock Core specimens under varying States of Stress and Temperatures. D7012-10.

[6] Başarır H., Kumral M., Özsan, A. (2004).Kayaçların tek eksenlibasınç dayanımının basit deney yöntemleriyle tahmini. KAYAMEK'2004-VII. Bölgesel Kaya Mekaniği Sempozyumu (In Turkish).

[7] Bieniawski, Z.T. (1975). The point-load test in geotechnical practice. Engineering Geology, Vol 9. Pergamon Press, pp. 669-697. https://doi.org/10.1016/0013-7952(75)90024-1.

[8] Broch, E., Franklin, J.A. (1972). The point-load strength test. International Journal of Rock Mechanics and Mining Sciences, Vol 9. Pergamon Press pp. 669-697. https://doi.org/10.1016/01489062(72)90030-7.

[9] Cargill, J.S., Shakoor, A. (1990). Evaluation of empirical methods for measuring uniaxial compressive strength of rock. Int. J. Rock Mec. Min. Sci. 27(6), 495-503. https://doi.org/10.1016/01489062(90)91001-N.

[10] Chou, K.T., Wong, R.H.C. (1996). Uniaxial compressive strength and point load strength. Int. J. Rock. Mec. Min. Sci. 33, 183-188. https://doi.org/10.1016/0148-9062(95)00056-9. 
[11] Çakır, Ş. (2000).Demirciler-Sadıklar-Gündoğdu-Tütünçiftlik (Kocaeli) Bölgesinin Jeolojisi. KOÜ Fen Bilimleri Enstitüsü Doktora Tezi (Yayınlanmamış), İzmit (In Turkish)

[12] D'Andrea, D.V., Fisher, R.L., Fogelson, D.E. (1964). Prediction of compression strength from other rock properties. Colo. Sch. Mines Q. v: 59(4B), 623-40.

[13] Forster, I.R. (1983). The influence of core specimen geometry on the axial point-load test. Int. J Rock MechSci20, 291-295. https://doi.org/10.1016/0148-9062(83)90599-5.

[14] Göktan, R.M. (1988). A theoretical and practical analysis of rock rippability. Ph.D. thesis ITU Institute of Appl. Sciences, p.108 (in Turkish).

[15] Grasso, P., Xu, S., Mahtab, A. (1992). Problems and promises of index testing of rocks. Proc. 33rd US Symp. Rock Mech., Santa Fe, NM, Balkema, Rotterdam, 3-5 June 1992, 879-888.

[16] Gunsallus, K.L., Kulhawy, F.H. (1984). A comparative evaluation of rock strength measures. Int. J. Rock Mech. Min. Sci. 21, 233-248. https://doi.org/10.1016/0148-9062(84)92680-9.

[17] Hassani, F.P., Scoble, M.J.J, Whittaker, B.N. (1980). Application of point-load index test to strength determination of rock and proposal for new size-correction chart. D. A. Summers (Editor), Proc. 21st US Symp.. Rock Mech., Rolla, Missouri, 1980, 543-553.

[18] Inoue, M.,Ohomi, M. (1981). Relation between uniaxial compressive strength and elastic wave velocity of soft rock. Proc. Int. Sym. on Weak Rock, Tokyo, pp. 9-13.

[19] ISRM (2007). The Complete ISRM Suggested Methods for Rock Characterization, Testing and Monitoring: 1974-2006. (Editors: Ulusay R. and Hudson JA), Kozan Ofset Matbaacılık Ankara.

[20] ISRM (1981). Rock characterization testing \& monitoring. ISRM Suggested Methods, New York: Pergamon Press, p.211 Editor: Brown ET.

[21] Kahraman, S. (1996).Basınç tahmininde Schmidt ve nokta yük indeksi kullanmanın güvenilirliği. K.T.U. Jeoloji Mühendisliği Bölümü, vol. 30 Yıl Sempozyumu. Bildiriler Kitabı, Trabzon, pp. 362-369. (In Turkish).

[22] Kahraman, S. (2001). Evaluation of simple method for assessing the uniaxial compressive strength of rock. Int. J. Rock Mech. Min. Sci., Geomechanics Abstract, 38, 981-994. https://doi.org/10.1016/S1365-1609(01)00039-9.

[23] Kahraman, S., Yeken, T. (2008). Determination of physical properties of carbonate rocks from P-wave velocity. Bull.Eng.Geol.Environ, v.67, p.277-281. https://doi.org/10.1007/s10064-008-0139-0.

[24] Kaya, O. (1978). İstanbul Ordovisiyeni ve Silüriyeni. H.Ü. Yerbilimleri Dergisi, cilt 4, 1-2, 1-22. (In Turkish).

[25] Kurtuluş, C.,Çakır, Ş. (2009).Çenedă̆ Formasyonu (Alt Triyas) Kumtaşlarının Fiziksel Özelliklerinin P-Dalgahızı Ölçümleri ile Belirlenmesi, Uygulamalı Yerbilimleri., Haziran 2009. s. 18-24. (In Turkish).

[26] Kurtuluş, C., Bozkurt, A,, Endeş, H. (2011). The physical and mechanical properties of serpentinized ultrabasic rocks in NW Turkey. Pure and Applied Geophysics, Volume 169, Issue 7, pp 1205-1215.

[27] Read, J.R.L., Thornten, P.N., Regan, W.M. (1980). A rational approach to the point load test. Proc. 3rd Australian-New Zealand Geomechanics Conference, vol. 2, p.35-39

[28] Yaşar, E., Erdoğan, Y. (2004). Correlating sound velocity with the density, compressive strength and Young's modulus of carbonate rocks. Int. J. Rock Mech. Min. Sci., 2004, vol 41, pp. 871-875. https://doi.org/10.1016/j.ijrmms.2004.01.012. 